\title{
Organic food-related educational actions developed by dieticians in Brazilian municipal schools
}

\author{
Ações educativas sobre alimentação orgânica \\ desenvolvidas por nutricionistas em escolas \\ municipais brasileiras
}

Tayse Valdira VIEIRA ${ }^{1}$

Arlete Catarina Tittoni CORSO ${ }^{1}$

David Alejandro GONZÁLEZ-CHICA ${ }^{1,2}$

A B S T R A C T

\section{Objective}

This study describes educational actions concerning organic foods conducted in Brazilian public schools and investigates how these actions are associated with the weekly workload and duration of employment of the dietician responsible for school meals.

\section{Methods}

In 2012 this cross-sectional, census-type study used an electronic questionnaire to collect data from dieticians or others responsible for school meals in all 5,565 Brazilian municipalities. The software Stata 11.0 was used for the statistical analyses.

\section{Results}

Although all Brazilian municipalities were contacted, $93.1 \%(n=5,184)$ replied. Of these, $94.2 \%$ had dieticians in charge of the school meals. Organic food-related educational actions were provided in the schools of $37.9 \%$ of the municipalities. The main actions were school gardening (67.1\%) and development of educational material (50.7\%). Having a dietician responsible for school meals was not associated with the existence of educational actions at school $(p=0.372)$. However, municipalities with dieticians in charge of school meals for at least twelve months were $22.0 \%$ and $20.0 \%$, respectively, more likely to provide educational actions at school and include the subject 'organic foods' in the municipal school curriculum ( $p<0.05$ for both). Dieticians' weekly work hours was directly related to the performance of school gardening-related activities $(p=0.016)$.

${ }^{1}$ Universidade Federal de Santa Catarina, Centro de Ciências da Saúde, Programa de Pós-Graduação em Nutrição. Campus Universitário Reitor João David Ferreira Lima, R. Delfino Conti, s/n., Trindade, 88040-900, Florianópolis, SC, Brasil. Correspondência para/Correspondence to: DA GONZÁLEZ-CHICA. E-mail: <david.epidemio@gmail.com>.

2 Universidade Federal de Santa Catarina, Centro de Ciências da Saúde, Programa de Pós-Graduação em Saúde Coletiva. Florianópolis, SC, Brasil. 


\section{Conclusion}

The percentage of Brazilian municipalities that provide organic food-related educational actions at school is low. Additionally, the availability of such actions relates to the dietician's duration of employment and weekly work hours.

Indexing terms: School feeding. Food organic. Food and nutrition education. Dietician.

\section{R E S U MO}

\section{Objetivo}

O estudo descreve ações educativas de alimentação orgânica, realizadas nas escolas municipais brasileiras, e investiga sua associação com o tempo de serviço do nutricionista responsável técnico e com a carga horária semanal por ele exercida.

\section{Métodos}

Trata-se de estudo transversal do tipo censo que, em 2012, entrevistou, mediante questionário eletrônico, o nutricionista responsável técnico ou outro responsável pela alimentação escolar em todos os 5565 municípios brasileiros. O software Stata 11.0 foi usado nas análises.

\section{Resultados}

Foram contatados todos os municípios brasileiros, dos quais $93,1 \%$ responderam ( $n=5184)$. Muito embora 94,2\% dos respondentes tenham afirmado possuir nutricionista responsável técnico, em apenas 37,9\% dos municípios foram realizadas ações educativas de alimentação orgânica nas escolas, com predomínio de horta escolar $(67,1 \%)$ e confecção de materiais educativos $(50,7 \%)$. Não se observou associação entre a presença de nutricionista responsável técnico e a realização de ações educativas $(p=0,372)$. Porém, a realização de ações educativas e a inserção do tema alimentação orgânica no Projeto Pedagógico do município foram, respectivamente, 22,0\% e 20,0\% maiores nos municípios em que o nutricionista responsável técnico trabalhava há pelo menos 12 meses, em relação àqueles em que esse profissional estava no cargo há menos tempo ( $p<0,05$ em ambos). Observou-se também uma relação direta entre a carga horária semanal de trabalho do nutricionista responsável técnico e a realização de atividades de horta escolar $(p=0,016)$.

\section{Conclusão}

O percentual de municípios brasileiros em que são realizadas atividades educativas sobre alimentação orgânica nas escolas, é baixo estando esta atividade relacionada com o tempo de contratação e a carga horária de trabalho dos nutricionistas responsáveis técnicos.

Termos de Indexação: Alimentação escolar. Alimentos orgânicos. Educação alimentar e nutricional. Nutricionista.

\section{INTRODUCTION}

The Programa Nacional de Alimentação Escolar (PNAE, National School Food Program) is one of Brazil's oldest social programs in the area of food and nutrition security'. Implemented in 1955, it currently relies on the transfer of funds to the Fundo Nacional de Desenvolvimento da Educação (FNDE, National Education Development Fund). It aims to provide food to students attending basic education (kindergartens, elementary schools, high schools, and education for youth and adults) in Brazilian public and philanthropic schools².
One of Programa Nacional de Alimentação Escolar's objectives is to ensure that all basic education students enrolled in Brazilian public and philanthropic schools develop healthy food habits. These healthy habits can be encouraged by food and nutrition education actions and the provision of nutritious meals ${ }^{3}$.

Concern with the quality of school meals is constant, and one of the aspects reinforced by PNAE policies is the consumption of organic foods ${ }^{4}$ to hopefully reduce the chronic effects associated with pesticide exposure ${ }^{5-7}$. Exposure of children and adolescents to pesticides deserves 
special attention because vulnerability to certain chemicals is greater during the development of the endocrine, reproductive, immune, visual, and nervous systems ${ }^{8}$. Additionally, consumption of family farm products encourages local production, regional development, and maintenance of farmers in the business ${ }^{3}$. Hence, Resolution 26 passed on June 17, 2013, determined that foods purchased for school meals should preferably consist of organic and/or agroecological products ${ }^{4}$.

Given the recency of the subject and scarcity of related studies, in 2010 the Centro Colaborador em Alimentação e Nutrição do Escolar of Santa Catarina (Cecane/SC, Santa Catarina's Collaboration Center for Schoolchildren's Food and Nutrition) conducted a survey in the state to investigate the presence of family farm and organic products in school meals. One year after the resolution passed, only 54 (20.5\%) municipalities were including organic foods in school meals 9 .

To carry out these guidelines and other PNAE policies correctly, dieticians play an essential role in encouraging students to develop healthy food practices and consume family farm and organic products ${ }^{10}$. Resolution CD/FNDE $n^{\circ} 26$ passed on June 17, 2013, requires the provision of the following food and nutrition actions in schools: supply of healthy foods; inclusion of the subject 'food and nutrition' in the school curriculum; promotion of healthy regional foods and cultural habits; promotion of organic and/or agroecological products and socio-biodiversity; and use of food as a teaching tool in food and nutrition-related educational actions ${ }^{4}$. However, little is known about the actions provided by the dieticians responsible for school meals affiliated with the municipal departments of education and PNAE for this issue, especially regarding educational actions in schools.

Only one study done in 2007 in the Northeast Region interviewed dieticians about this subject ${ }^{11}$ and found that $33 \%$ of the interviewees conducted educational activities regularly.
Hence, despite PNAE's efforts to stimulate the development of healthy food habits, little is known about the educational actions conducted by dieticians in each municipality to encourage the intake of family farm and organic products or whether dieticians' weekly work hours are enough for them to carry out all the duties established by PNAE's policies. Hence, the study of this subject is critical for the creation of a nationwide profile of the educational actions related to family farm and organic foods conducted in schools and to determine whether dieticians are being overworked by PNAE. The present study aims to investigate the presence of organic foodrelated educational actions in Brazilian municipal schools in 2012 and their possible association with dieticians' weekly work hours and duration of employment.

\section{METHODS}

This is a quantitative, exploratory, descriptive, and analytical study. The study population consisted of dieticians, secretaries of education, or the individuals responsible for the school meals served in 5,565 Brazilian municipalities.

A questionnaire was sent to all Brazilian municipalities to collect data. It contained 38 questions divided into three blocks (dietician actions and supply of family farm and organic products).

The first study stage consisted of creating a contact list with the e-mails and telephone numbers of the departments of education and/ or of the dieticians responsible for the school meals in all Brazilian municipalities by contacting the state departments of education and the Cecane of other regions and states, and by searching the official sites of the municipal departments of education.

A digital questionnaire created in the "Form" tools of Google Docs was used for data collection. The questionnaire was sent to the municipal contact's e-mail three times at fifteen- 
day intervals. If the questionnaire was not answered after three tries, up to two telephone calls were made to sensitize the individual in charge of school meals to the importance of the study. If the questionnaire was still not answered after these telephone calls, a third telephone call was made to interview the person by telephone.

Data were collected from February to September 2012 by a team of eight duly trained individuals. The municipalities were divided homogeneously by state among the data collectors.

The dieticians' characteristics used as exposure variables are weekly work hours, duration of employment, gender, and age. Weekly work hours was considered a discrete variable (total number of hours that the dietician works for the municipality) and analyzed as a categorical variable (<30 hours; 30 hours; 31-60 hours). Duration of employment was also considered a discrete variable (dietician's total duration of employment in the municipality) and analyzed as categorical variable ( $<12$ months; $12-47$ months; $\geq 48$ months). These categories considered the usual hiring time of the dieticians in the municipalities ${ }^{10}$. The dieticians' demographic variables included gender (female or male) and age (collected as discrete variable and analyzed as categorical variable: 20-29; 30-39; and $\geq 40$ years).

The dependent variables were the educational actions conducted by the dieticians in the schools and included: 1) inclusion of the subject 'organic foods' in the school curriculum; 2) provision of educational actions to encourage the intake of organic foods (yes or no); and 3) types of educational actions provided (school gardening, development of educational material, culinary workshops, recreational activities, handson interdisciplinary classes, and field trips to family farms). All these variables were dichotomous (yes/no).

Google Docs automatically created an Excel database to process the data. The database was then converted by the software Stat Transfer and analyzed by the statistical package Stata 11.0.

The descriptive analyses included the absolute and relative frequencies of the categorical variables with their respective 95\% Confidence Interval $(95 \% \mathrm{Cl})$, and the median and interquartile interval (p25-p75) of the discrete variables (weekly work hours and duration of employment).

The descriptive analyses included bivariate analyses by the chi-square test to measure the differences between Brazilian regions and states. Poisson regression measured the association between the exposure variables (presence of dietician, weekly work hours, and duration of employment) with the outcomes 'performance of educational actions at school' and 'inclusion of the subject 'organic foods' in the school curriculum.' Likewise, dietician's duration of employment and weekly work hours were adjusted mutually. After adjustment for confounders, the prevalences were estimated by Stata's command 'margins.' The significance level was set at $5 \%$ for all analyses $(p<0.05)$. The percentage of participating municipalities was calculated to determine the sampling weights (weight was defined as the inverse of the probability of replying, by state) of the descriptive and association analyses.

The project was approved by the Human Research Ethics Committee of the Universidade Federal de Santa Catarina as determined by Resolution $n^{\circ} 196 / 96$ of the National Health Council (01101512.9.0000.0121, Opinion 21563).

\section{RES U L T S}

The results were tabulated to organize the data. Table 1 shows that 5,184 municipalities participated in the study, corresponding to $93.1 \%$ of the 5,565 Brazilian municipalities. The greatest and smallest participations occurred in the South $(98.7 \%)$ and North (86.6\%) regions, respectively $(p<0.001)$. The states with the highest percentage of respondents were Mato Grosso do Sul, Espírito 
Santo, and Santa Catarina (100.0\% reply rate), and the lowest, Maranhão (75.6\%; $p<0.001)$. These reply percentages were used as sampling weights for estimate correction.

Table 1 also shows that $94.2 \%$ of the municipalities had a dietician in charge of the school meals, with the Midwest (88.4\%) and North $(82.1 \%)$ regions being below the national average $(p<0.001)$. These percentages also varied within regions. In these two regions, the percentages were smaller in the states of Mato Grosso (78.4\%) and Tocantins (64.6\%), respectively. On the other hand, some states in these same regions had dieticians in charge of school meals in more than $90.0 \%$ of their municipalities, such as Mato Grosso do Sul (Midwest) and Pará and Roraima (North).

The respondents in $81.9 \%, 12.1 \%$, and $6.0 \%$ of the municipalities were dieticians, secretaries of education, and other, respectively. The percentages of dieticians who answered the questionnaires were higher in the South (86.7\%) and Southeast (87.6\%) and smaller in the North $(65.3 \%)(p<0.001$ between the former regions and the latter).

Table 1. Municipalities that responded and presence of dieticians by Brazilian regions and states. Brazil, 2012.

\begin{tabular}{|c|c|c|c|c|c|c|}
\hline \multirow{2}{*}{ Brazilian regions and states } & \multirow{2}{*}{$\frac{\text { Total municipalities in } 2011^{\mathrm{a}}}{\mathrm{N}}$} & \multicolumn{3}{|c|}{ Responders } & \multicolumn{2}{|c|}{ Have dietician } \\
\hline & & $\mathrm{N}$ & $\%$ & $p^{*}$ & $\%($ IC95\%) & $p^{*}$ \\
\hline Brazil & 5,565 & 5,184 & 93.1 & $<0.001^{* *}$ & $94.2(93.6 ; 94.8)$ & $<0.001^{* *}$ \\
\hline North & 448 & 388 & 86.6 & $0.030^{* * *}$ & $82.1(78.3 ; 85.9)$ & $<0.001^{* * *}$ \\
\hline Acre & 22 & 20 & 90.9 & & $85.0(67.8 ; 100.0)$ & \\
\hline Amapá & 16 & 13 & 81.2 & & $76.9(50.4 ; 100.0)$ & \\
\hline Pará & 143 & 118 & 82.5 & & $94.9(90.9 ; 98.9)$ & \\
\hline Rondônia & 51 & 49 & 96.1 & & $89.8(81.0 ; 98.6)$ & \\
\hline Roraima & 15 & 13 & 86.7 & & $100.0 \quad(-)$ & \\
\hline Tocantins & 139 & 127 & 91.4 & & $64.6(56.1 ; 73.0)$ & \\
\hline Northeast & 1,794 & 1,581 & 88.1 & $<0.001^{* * *}$ & $96.3(95.4 ; 97.2)$ & $0.014^{* * *}$ \\
\hline Maranhão & 217 & 164 & 75.6 & & $96.3(93.4 ; 99.2)$ & \\
\hline Paraíba & 223 & 201 & 90.1 & & $91.5(87.7 ; 95.4)$ & \\
\hline Pernambuco & 185 & 158 & 85.4 & & $96.8(94.1 ; 99.6)$ & \\
\hline Piauí & 224 & 182 & 81.2 & & $95.1(91.9 ; 98.2)$ & \\
\hline Rio Grande do Norte & 167 & 156 & 93.4 & & $97.4(94.9 ; 99.9)$ & \\
\hline Sergipe & 75 & 72 & 96.0 & & $100.0 \quad(-)$ & \\
\hline Midwest & 466 & 455 & 97.6 & $0.123^{* * *}$ & $88.4(85.4 ; 91.3)$ & $<0.001^{* * *}$ \\
\hline Distrito Federal and Goiás & 247 & 238 & 96.4 & & $91.2(87.5 ; 94.8)$ & \\
\hline Mato Grosso & 141 & 139 & 98.6 & & $78.4(71.5 ; 85.3)$ & \\
\hline South & 1,188 & 1,173 & 98.7 & $<0.001^{* * *}$ & $97.2(96.2 ; 98.1)$ & $0.560^{* * *}$ \\
\hline Paraná & 399 & 385 & 96.5 & & $96.6(94.8 ; 98.4)$ & \\
\hline Rio Grande do Sul & 496 & 495 & 99.8 & & $97.8(96.5 ; 99.1)$ & \\
\hline Santa Catarina & 293 & 293 & 100.0 & & $96.9(94.9 ; 98.9)$ & \\
\hline
\end{tabular}

Note: ${ }^{a}$ Source: Instituto Brasileiro de Geografia e Estatística. Cities, 2011; ${ }^{*}$ Chi-square heterogeneity; ${ }^{* *} p$-value of the interregional difference;

${ }^{* * *} p$-value of the difference between same-region states. 
Only municipalities with dieticians in charge of school meals $(n=4,883)$ were included in the analyses regarding weekly work hours and duration of employment. Dieticians worked a median of 20 hours per week (interquartile range of 20-30 hours per week). The median duration of employment was 31.5 months (interquartile range of 14-60 months).

Table 2 shows that 4,883 municipalities employ dieticians, and in $56.7 \%$ of these municipalities they work less than 30 hours a week. The two regions that exceeded the national average were the North and the South $(p<0.001)$.

Table 2 also shows that more than twothirds of the dieticians had worked in the municipality for less than 48 months, especially in the Midwest, Northeast, and North, with percentages in excess of $70 \%(p<0.001)$.

Few municipalities $(37.9 \%$; $95 \% \mathrm{Cl}=36.5$ 39.3) introduced the subject 'organic foods' in

Table 2. Dieticians weekly work hours, duration of employment, and performance of educational actions by Brazilian region and state. Brazil, 2012.

\begin{tabular}{|c|c|c|c|c|c|c|c|c|}
\hline \multirow{2}{*}{$\begin{array}{l}\text { Brazilian region } \\
\text { and state }\end{array}$} & \multicolumn{3}{|c|}{ Dietician works $<30 \mathrm{~h} /$ week } & \multicolumn{2}{|c|}{ Dietician works $<48$ months } & \multicolumn{3}{|c|}{ Dietician performs educational actions } \\
\hline & $\mathrm{N}^{\mathrm{a}}$ & $\%(95 \mathrm{Cl} \%)^{\mathbf{b}}$ & $p^{*}$ & $\%(95 \mathrm{Cl} \%)^{\mathbf{b}}$ & $p^{*}$ & $\mathrm{~N}^{\mathrm{c}}$ & $\%(95 \mathrm{Cl} \%)^{d}$ & $p^{*}$ \\
\hline Brazil & 4,883 & $56.7(55.3 ; 58.1)$ & $<0.001^{* *}$ & $67.9(66.6 ; 69.2)$ & $<0.001^{* *}$ & 5184 & $37.9(36.5 ; 39.3)$ & $0.054^{* *}$ \\
\hline North & 317 & $50.3(44.8 ; 55.9)$ & $<0.001^{* * *}$ & $76.6(71.9 ; 81.3)$ & $0.015^{* * *}$ & 388 & $37.8(32.7 ; 43.0)$ & $0.069^{* * *}$ \\
\hline Acre & 17 & $70.6(46.4 ; 94.7)$ & & $52.9(26.5 ; 79.4)$ & & 20 & $41.2(15.1 ; 67.3)$ & \\
\hline Amapá & 10 & $20.0(0.0 ; 50.2)$ & & $80.0(49.8 ; 100.0)$ & & 13 & $16.7(0.0 ; 41.4)$ & \\
\hline Amazonas & 39 & $36.8(20.8 ; 52.9)$ & & $89.5(79.2 ; 99.7)$ & & 48 & $46.5(31.0 ; 62.0)$ & \\
\hline Pará & 112 & $35.7(26.7 ; 44.7)$ & & $70.5(62.0 ; 79.1)$ & & 118 & $31.4(22.2 ; 40.5)$ & \\
\hline Rondônia & 44 & $43.2(27.9 ; 58.4)$ & & $70.0(56.4 ; 84.5)$ & & 49 & $35.7(20.6 ; 50.8)$ & \\
\hline Roraima & 13 & $61.5(30.9 ; 92.1)$ & & $84.6(61.9 ; 100.0)$ & & 13 & $15.4(0.0 ; 38.1)$ & \\
\hline Tocantins & 82 & $81.7(73.2 ; 90.2)$ & & $85.2(77.3 ; 93.1)$ & & 127 & $46.0(36.7 ; 55.3)$ & \\
\hline Northeast & 1,522 & $65.5(63.1 ; 67.9)$ & $0.008^{* * *}$ & $74.6(72.3 ; 76.8)$ & $<0.001^{* * *}$ & 1581 & $37.8(35.3 ; 40.4)$ & $0.019^{* * *}$ \\
\hline Alagoas & 89 & $68.5(58.7 ; 78.4)$ & & $57.3(46.8 ; 67.8)$ & & 90 & $33.3(21.9 ; 44.7)$ & \\
\hline Bahia & 376 & $64.0(59.1 ; 68.9)$ & & $82.3(78.4 ; 86.2)$ & & 388 & $37.8(33.6 ; 44.0)$ & \\
\hline Ceará & 165 & $66.5(59.2 ; 73.7)$ & & $62.2(54.7 ; 69.7)$ & & 170 & $34.7(27.0 ; 42.5)$ & \\
\hline Maranhão & 158 & $71.3(64.2 ; 78.5)$ & & $80.8(74.5 ; 87.0)$ & & 164 & $39.6(31.3 ; 47.8)$ & \\
\hline Paraíba & 184 & $72.5(66.0 ; 79.1)$ & & $76.4(70.1 ; 82.6)$ & & 201 & $41.6(34.5 ; 48.6)$ & \\
\hline Pernambuco & 173 & $54.3(46.3 ; 62.3)$ & & $72.0(64.7 ; 79.3)$ & & 158 & $40.0(31.8 ; 48.2)$ & \\
\hline Piauí & 173 & $61.3(53.9 ; 68.6)$ & & $70.0(63.0 ; 76.8)$ & & 182 & $36.7(29.3 ; 44.2)$ & \\
\hline Rio Grande do Nort & te 152 & $62.9(55.1 ; 70.7)$ & & $72.8(65.7 ; 80.0)$ & & 156 & $42.7(34.7 ; 50.7)$ & \\
\hline Sergipe & 72 & $75.7(65.4 ; 86.0)$ & & $87.1(79.1 ; 95.2)$ & & 72 & $13.3(4.5 ; 22.2)$ & \\
\hline Midwest & 402 & $52.8(47.9 ; 57.7)$ & $<0.001^{* \star *}$ & $72.2(67.8 ; 76.6)$ & $0.124^{* * *}$ & 455 & $39.6(34.8 ; 44.4)$ & $0.040^{* \star *}$ \\
\hline Goiás and DF & 217 & $63.1(56.7 ; 69.6)$ & & $76.0(70.3 ; 81.8)$ & & 238 & $43.8(37.0 ; 50.6)$ & \\
\hline Mato Grosso & 109 & $41.3(31.9 ; 50.7)$ & & $69.7(61.0 ; 78.5)$ & & 139 & $39.3(30.5 ; 48.1)$ & \\
\hline Mato Grosso do Su & iul 76 & $39.5(28.2 ; 50.7)$ & & $64.5(53.5 ; 75.5)$ & & 78 & $26.1(15.2 ; 37.1)$ & \\
\hline Southeast & 1,503 & $45.8(43.2 ; 48.3)$ & $<0.001^{* \star \star}$ & $62.5(60.1 ; 65.0)$ & $<0.001^{* * *}$ & 1587 & $35.1(32.6 ; 37.6)$ & $0.523^{* * *}$ \\
\hline Espírito Santo & 76 & $36.8(25.7 ; 47.9)$ & & $71.2(61.1 ; 82.1)$ & & 78 & $30.2(18.5 ; 41.8)$ & \\
\hline Minas Gerais & 745 & $54.8(51.3 ; 58.4)$ & & $73.0(69.8 ; 76.2)$ & & 809 & $36.7(33.3 ; 40.2)$ & \\
\hline Rio de Janeiro & 80 & $61.2(50.3 ; 72.2)$ & & $63.3(52.4 ; 74.2)$ & & 85 & $35.2(23.8 ; 46.6)$ & \\
\hline São Paulo & 602 & $33.4(29.6 ; 37.2)$ & & $48.1(44.1 ; 52.2)$ & & 615 & $33.3(29.1 ; 37.4)$ & \\
\hline South & 1,139 & $62.1(59.3 ; 64.9)$ & $<0.001^{* * *}$ & $61.0(58.2 ; 63.9)$ & $0.004^{* * *}$ & 1173 & $41.1(38.2 ; 44.1)$ & $0.018^{* * *}$ \\
\hline Paraná & 153 & $55.0(49.9 ; 60.1)$ & & $60.3(55.3 ; 65.3)$ & & 385 & $35.1(30.0 ; 40.2)$ & \\
\hline Rio Grande do Sul & 484 & $70.1(66.0 ; 74.2)$ & & $56.9(52.4 ; 61.4)$ & & 495 & $43.5(38.9 ; 48.1)$ & \\
\hline Santa Catarina & 284 & $58.1(52.3 ; 63.9)$ & & $69.0(63.6 ; 74.4)$ & & 293 & $45.1(39.1 ; 51.1)$ & \\
\hline
\end{tabular}

Note: aNumber corresponding to municipalities with dieticians in charge of school meals; ${ }^{b}$ Percentage in relation to the municipalities that have dieticians in charge of school meals; ' ${ }^{N}$ umber of responding municipalities; ${ }^{\mathbf{d} P e r c e n t a g e ~ o f ~ r e s p o n d i n g ~ m u n i c i p a l i t i e s ; ~}{ }^{*}$ Chi-square for heterogeneity; ${ }^{* *} p$-value of the interregional differences; ${ }^{* * *} p$-value of the difference between states in each region. 95\% Cl: 95\% Confidence Interval. 
the school curriculum (Table 2). This percentage was slightly higher in the South $(41.1 \%)$, but the interregional differences were not significant. Again the North and Northeast stand out with some states having percentages below 20.0\%, namely Sergipe (13.3\%), Amapá (16.7\%), and Roraima (15.4\%). Percentages above $40.0 \%$ were found in Goias and Distrito Federal (Midwest), Paraiba and Rio Grande do Norte (Northeast), Acre, Amazonas, and Tocantins (North), and finally, Rio Grande do Sul and Santa Catarina (South).

Table 3 shows the main educational actions developed in 1,626 Brazilian municipalities. The main educational action was school gardening $(67.1 \%)$, followed by development of educational material (50.7\%). The North and South had the highest percentages of municipalities ( $>70.0 \%)$ using school gardening as an educational strategy, while the Northeast and Southeast had the lowest $(<66 \%)(p=0.017)$. On the other hand, the regions with the highest percentages of municipalities developing educational materials were the
Midwest and Southeast, and with the smallest, the North and South $(p=0.015)$. Culinary workshops were held in $26.3 \%$ of the municipalities, and the percentage was highest in the South $(p=0.006)$. Other strategies were less common and presented no interregional differences ( $p>0.05$ for all cases).

Municipalities with dieticians in charge of school meals were more likely to carry out educational actions at school (38.1\%; $95 \% \mathrm{Cl}=36.6-39.5$ versus $35.4 \% ; 95 \% \mathrm{Cl}=29.9$ 40.9) but the difference was not significant ( $p=0.372$; values adjusted for gender, age, and state). Municipalities with dieticians were also more likely to include the subject 'organic foods' in the school curriculum $(31.9 \% ; 95 \% \mathrm{Cl}=24.0$ 34.7 versus $29.4 \% ; 95 \% \mathrm{Cl}=30.5-33.3)$, but again, not significantly ( $p=0.388$; values adjusted for gender, age, and state).

Table 4 shows the association between the dieticians' weekly work hours and the inclusion of organic foods in the educational actions and

Table 3. Actions taken to introduce the subject organic foods in schools by Brazilian region. Brazil, 2012.

\begin{tabular}{|c|c|c|c|c|c|c|c|c|}
\hline \multirow{3}{*}{$\begin{array}{l}\text { Organic food-related } \\
\text { educational actions }\end{array}$} & \multirow{2}{*}{\multicolumn{2}{|c|}{ Brazil }} & \multicolumn{5}{|c|}{ Brazilian regions } & \multirow{3}{*}{$p^{*}$} \\
\hline & & & \multirow{2}{*}{$\begin{array}{c}\text { North } \\
\%(95 \% \mathrm{Cl}) \\
\end{array}$} & \multirow{2}{*}{$\begin{array}{c}\text { Northeast } \\
\%(95 \% \mathrm{Cl})\end{array}$} & \multirow{2}{*}{$\frac{\text { Midwest }}{\%(95 \% \mathrm{Cl})}$} & \multirow{2}{*}{$\begin{array}{l}\text { Southeast } \\
\%(95 \% \mathrm{Cl})\end{array}$} & \multirow{2}{*}{$\begin{array}{c}\text { South } \\
\%(95 \% \mathrm{Cl})\end{array}$} & \\
\hline & $\mathrm{N}^{\mathrm{a}}$ & $\%(95 \% \mathrm{Cl})$ & & & & & & \\
\hline \multirow[t]{2}{*}{ School garden } & & 67.1 & 73.4 & 62.8 & 69.9 & 65.6 & 72.1 & \\
\hline & 1,096 & $(64.8 ; 69.4)$ & $(64.8 ; 82.1)$ & $(58.5 ; 67.0)$ & $(62.0 ; 77.7)$ & $(61.2 ; 70.0)$ & $(67.8 ; 76.4)$ & 0.017 \\
\hline \multirow{2}{*}{$\begin{array}{l}\text { Development of } \\
\text { educational material }\end{array}$} & & 50.7 & 43.1 & 50.1 & 53.8 & 56.1 & 45.5 & \\
\hline & 822 & $(48.2 ; 53.1)$ & $(33.3 ; 52.8)$ & $(46.5 ; 55.2)$ & $(45.3 ; 62.2)$ & $(51.5 ; 60.6)$ & $(40.7 ; 50.3)$ & 0.015 \\
\hline \multirow[t]{2}{*}{ Culinary workshops } & & 26.3 & 24.9 & 23.0 & 19.1 & 27.4 & 32.4 & \\
\hline & 432 & $(24.2 ; 28.4)$ & $(16.4 ; 33.3)$ & $(19.3 ; 26.7)$ & $(12.4 ; 25.8)$ & $(23.3 ; 31.5)$ & $(27.9 ; 36.9)$ & 0.006 \\
\hline \multirow[t]{2}{*}{ Recreational activities } & & 25.2 & 29.3 & 23.1 & 27.3 & 24.3 & 27.0 & \\
\hline & 408 & $(23.2 ; 27.3)$ & $(20.3 ; 38.3)$ & $(19.4 ; 26.8)$ & $(19.7 ; 34.8)$ & $(20.4 ; 28.3)$ & $(22.8 ; 31.3)$ & 0.498 \\
\hline \multirow{2}{*}{$\begin{array}{l}\text { Hands-on } \\
\text { interdisciplinary classes }\end{array}$} & & 23.7 & 22.3 & 27.1 & 22.0 & 23.4 & 20.4 & \\
\hline & 384 & $(21.6 ; 25.7)$ & $(14.1 ; 30.5)$ & $(23.2 ; 30.9)$ & $(15.0 ; 29.1)$ & $(19.4 ; 27.3)$ & $(16.5 ; 24.2)$ & 0.190 \\
\hline \multirow[t]{2}{*}{ Field trips to family farms } & & 12.2 & 8.4 & 11.5 & 13.9 & 10.8 & 15.4 & \\
\hline & 201 & $(10.7 ; 13.8)$ & $(3.0 ; 13.8)$ & $(8.7 ; 14.2)$ & $(8.0 ; 19.8)$ & $(7.9 ; 13.7)$ & $(11.9 ; 18.9)$ & 0.155 \\
\hline \multirow[t]{2}{*}{ Other } & & 5.3 & 5.4 & 6.4 & 5.9 & 4.6 & 4.5 & \\
\hline & 87 & $(4.2 ; 6.4)$ & $(1.1 ; 9.7)$ & $(4.2 ; 8.5)$ & $(1.2 ; 9.9)$ & $(2.7 ; 6.6)$ & $(2.5 ; 6.5)$ & 0.700 \\
\hline
\end{tabular}

Note: aNumber of municipalities with dieticians in charge of school meals that perform organic food-related educational actions in schools; ${ }^{*}$ Chi-square of the interregional differences.

95\% Cl: 95\% Confidence Interval 
Table 4. Dieticians' weekly work hours and duration of employment (months) association with educational actions performed in 2011. Brazil, 2012

\begin{tabular}{|c|c|c|c|c|c|c|c|c|}
\hline \multirow{3}{*}{ Educational actions } & \multicolumn{4}{|c|}{ Weekly work hours $^{\dagger}$} & \multicolumn{4}{|c|}{ Duration of employment (months) ${ }^{\dagger}$} \\
\hline & $\begin{array}{c}<30 h \\
(n=2,754)\end{array}$ & $\begin{array}{c}<30 h \\
(n=952)\end{array}$ & $\begin{array}{c}31-60 h \\
(n=1,156)\end{array}$ & $p$ & $\begin{array}{c}<12 m \\
(n=892)\end{array}$ & $\begin{array}{c}12-47 m \\
(n=2,388)\end{array}$ & $\begin{array}{c}\geq 48 m \\
(n=1,570)\end{array}$ & $p$ \\
\hline & $\%$ & $\%$ & $\%$ & & $\%$ & $\%$ & $\%$ & \\
\hline Develops educational actions & 36.9 & 37.5 & 36.9 & $0.154^{*}$ & 31.6 & 39.0 & 38.5 & $0.003^{* *}$ \\
\hline Included in the school curriculum & 30.6 & 31.9 & 30.6 & $0.083^{*}$ & 26.8 & 32.8 & 32.0 & $0.015^{* *}$ \\
\hline \multicolumn{9}{|l|}{ Main educational actions ${ }^{t \dagger}$} \\
\hline School garden activities & 64.7 & 68.9 & 64.7 & $0.016^{*}$ & 68.1 & 67.0 & 66.8 & $0.764^{*}$ \\
\hline Development of educational materials & 52.5 & 46.1 & 52.5 & $0.161^{* *}$ & 52.1 & 50.4 & 50.3 & $0.888^{* *}$ \\
\hline Recreational activities & 24.3 & 27.8 & 24.3 & $0.475^{* *}$ & 25.9 & 24.3 & 26.6 & $0.639^{* *}$ \\
\hline Culinary workshops & 25.5 & 26.2 & 25.5 & $0.521^{*}$ & 26.4 & 24.3 & 28.4 & $0.266^{* *}$ \\
\hline Hands-on interdisciplinary classes & 24.7 & 17.9 & 24.7 & $0.040^{* *}$ & 25.0 & 24.2 & 22.0 & $0.339^{*}$ \\
\hline Field trips to family farms & 13.0 & 12.0 & 13.0 & $0.295^{*}$ & 10.9 & 13.0 & 11.8 & $0.618^{* *}$ \\
\hline Other & 5.5 & 5.2 & 5.5 & $0.698^{*}$ & 3.2 & 6.2 & 4.8 & $0.180^{* *}$ \\
\hline
\end{tabular}

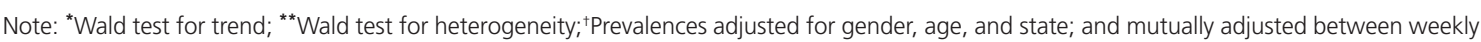
work load and duration of employment. Data obtained by Poisson regression; ${ }^{{ }^{\dagger}}$ Percentage regarding the number of municipalities that have dieticians in charge of school meals and conducted educational actions $(\mathrm{N}=1,626)$.

school curriculum. These two variables were directly related to the dieticians' weekly work hours, but the relationships were not significant ( $p>0.05$ for both). The percentage of municipalities with dieticians in charge of school meals for at least twelve months that conducted educational actions was roughly $22 \%$ higher than that of those with dieticians in charge for less than twelve months ( $p=0.003$ ). Also, $20 \%$ more municipalities with dieticians in charge of the school meals for at least twelve months as opposed to municipalities with dieticians in charge for less than twelve months included organic foods in the school curriculum ( $p=0.015)$. Dieticians' weekly work hours were also directly related to school garden-related activities $(p=0.016)$. Duration of employment was not associated with any type of educational action/strategy.

\section{DISCUSSION}

This is the first nationwide study that investigates the impact of a dietician responsible for PNAE in the municipal departments of education and the implementation of the subject 'organic foods' in the school curriculum as a basic strategy to encourage intake of these foods. This aspect is critical for the correct execution of the program, since Resolution CFN n' 465/2010 assigns dieticians many PNAE-related tasks, especially one to propose and carry out food and nutrition education actions in schools ${ }^{10}$. The importance of investigating this subject is justified by the dieticians' municipal role of guaranteeing schoolchildren's access to quality healthy foods in the required amounts and by the funds provided annually for this purpose. In the last three years, the resources provided by the federal government exceeded 3.0 billion reais per year ${ }^{2,12}$. In 2009 the Federal Law 11,947/2009 established that at least $30 \%$ of these resources should be used for acquiring family farm products ${ }^{3}$, and Resolution CD/FNDE $n^{\circ} 38$ passed on July 16, 2009 ${ }^{13}$, recommended prioritizing organic and/or agroecological foods ${ }^{4}$, a recommendation maintained by Resolution CD/FNDE n 26/2013, which revoked the previous resolution mentioned above. Hence, food and nutrition education given in schools on organic foods is justified from the health and economic viewpoints.

The study results show a disturbing situation: regardless of who is in charge of school meals, only one-third of the municipalities use 
educational actions to stimulate organic food intake. Consequently, students, teachers, and cooks would not be receiving the training and encouragement required by the secretaries of education on the importance of organic foods in school meals and as an educational action in schools. These data agree with those provided by Mello et al. ${ }^{11}$. in a study with 434 PNAE dieticians in the Northeast. Although this study did not include the subject organic foods, it found that only $33.2 \%$ of the interviewees carried out compulsory food and nutrition education actions regularly. Cunha et al. ${ }^{14}$ diagnosed organic foodrelated educational actions in a state school in Florianópolis (SC) and found that these actions were not included in the curriculum. Furthermore, teachers and students found it challenging to define and identify organic foods. Thus, the authors believe that dieticians should be responsible for school meals to help to introduce this subject in the curriculum, as recommended by PNAE.

Municipalities with dieticians in charge of school meals for less than twelve months were less likely to carry out educational actions and include the subject 'organic foods' in the school curriculum. This finding may be related to the dieticians' work conditions since irregularities were found in the hiring process, and there was high dietician turnover. More than half the dieticians hired irregularly work less than 30 hours a week, especially in the Northeast. There are minimum reference parameters for the correct performance of technical tasks required by PNAE so dieticians in charge of school meals should be hired to work at least 30 hours a week ${ }^{7}$. This time is necessary for dieticians to ensure quality meals to the schoolchildren, respecting their food habits and the agricultural potential of each community. Based on an administrative perspective, dieticians still need to make sure the municipality receives FNDE funds since the dietician is also responsible for the planning, coordination, direction, supervision, and assessment of the food and nutrition area of the municipal department of education dedicated to school meals ${ }^{3}$. Regarding hiring irregularities, Chaves et al. ${ }^{15}$ point out that, despite awareness of their responsibilities, dieticians face obstacles to perform them since they are often burdened by bureaucratic and administrative activities. Likewise, the results of the present study show that weekly work below 30 hours hinders one of the main educational actions, school gardening. The educational strategy 'school gardening' is promoted by FNDE in Brazilian municipalities by the project 'Educating with School Gardening'. This recreational strategy helps teachers to make children and adolescents aware of the importance of healthy food practices, strengthens regional cultures, and promotes environmental awareness ${ }^{16-18}$.

The results also show high dietician turnover since the mean duration of employment is below four years, especially in the North and Northeast. This datum is corroborated by the dieticians' ages (almost half of them were aged 20 to 29 years), suggesting that they are recent graduates. One reason for this high turnover is the way dieticians are hired by municipalities. Dieticians may choose among various labor contracts that do not require full-time employment, such as freelancers, who may provide services to departments of education as self-employed individuals or business owners/partners ${ }^{19}$. Thus, entities responsible for school meals (departments of education) may choose one of these hiring options depending on the municipal financial and political interests. High turnover is a limiting factor not only for the performance of educational activities on food and nutrition, such as discussing organic foods (which should be done by a dietician), but also for the performance of other activities required by PNAE. A 2007 study conducted in the Northeast with 434 dieticians responsible for school meals who participated in PNAE training activities found that duration of employment in PNAE was directly related to performance of the tasks required by the program ${ }^{11}$.

Another aspect that deserves attention is that although Law 11,947/2009 establishes that 
all Brazilian municipalities should have dieticians in charge of school meals, $5.8 \%(n=300)$ did not. This number may seem small but it varies greatly between states and regions, especially in the Midwest and North. The North region is exactly one of the regions that most experiences nutritional unbalances since only $59.7 \%$ of the households are food secure ${ }^{20}$. Today there are 400 nutrition programs in Brazil registered with the Ministry of Education. Registered nutrition programs are available in all states except Roraima ${ }^{21}$. Yet, all thirteen municipalities in Roraima that answered the questionnaire had a dietician in charge of school meals. Hence, the absence of dieticians in charge of school meals in $5.8 \%$ of the Brazilian municipalities (or in as much as $35.0 \%$ of the municipalities in some states) would not be related to the absence of dieticians in the labor market.

There are few studies in the literature on the performance of organic food-related educational actions in Brazilian municipal schools and their association with dieticians' weekly work hours or duration of employment, which together with the different methods used by those few studies, hinders comparison of the results and assessment of this situation over time in Brazil. Still, this lack of comparability does not affect the internal validity of the present data.

Limitations of this study include the smaller percentage of respondents in the North and Northeast regions, also the regions with smallest internet access. However, many strategies were employed to reduce the percentage of nonrespondents, including telephone calls, which enabled us to increase response rate considerably, especially in the two regions mentioned above, and achieve a response rate of $85 \%$. Sampling weights by state compensated this percentage of losses, reducing the probability that the percentage of nonrespondents would affect the results. Finally, the present study did not count the number of dieticians per municipality, which would help to assess compliance with PNAE's determinations and possibly improve result accuracy.

\section{CONCLUSION}

The percentage of Brazilian municipalities that perform organic-food related educational activities in schools is low, and these activities relate to the dieticians' weekly work hours and duration of employment. This suggests the many challenges that PNAE faces to best coordinate these educational actions with the various activities required of dieticians for the promotion of family farm and organic products.

The study results reflect the nationwide state of affairs, allowing regulatory agencies and especially, agents, to conduct actions and strategies that increase the number of dieticians in the secretaries of education and schools and that revise the hiring guidelines for these professionals and their respective work hours, making these compatible with their tasks.

\section{ACKNOWLEDGMENTS}

We thank the National Education Development Fund, Collaboration Center for Schoolchildren's Food and Nutrition of Santa Catarina, Santa Catarina's Department of Education, and everyone technically in charge of the school meals who participated in the study.

\section{CONTRIBUTORS}

TV VIEIRA, DA GONZÁLEZ-CHICA, and ACT CORSO helped to conceive the study; collect, analyze, and interpret the data; and write the manuscript.

\section{REFEREN CES}

1. Santos LMP, Santos SMC, Santana LAA, Henrique FCS, Mazza RPD, Santos LAS, et al. Avaliação de políticas públicas de segurança alimentar e combate à fome no período 1995-2002: 4. Programa Nacional de Alimentação Escolar. Cad Saúde Pública. 2007; 23(11):2681-93. doi: 10.1590/S0102-31 $1 \times 2007001100016$

2. Brasil. Fundo Nacional de Desenvolvimento da Educação. Alimentação escolar [Apresentação]. Brasília: FNDE; 2013 [acesso 2013 maio 27]. Disponível em: 
<http://www.fnde.gov.br/programas/alimentacaoescolar/alimentacao-escolar-apresentacao>.

3. Brasil. Ministério da Educação. Lei $n^{\circ} 11.947$, de 16 de julho de 2009. Dispõe sobre o atendimento da alimentação escolar e do Programa Dinheiro Direto na Escola aos alunos da educação básica. Brasília: MEC; 2012 [acesso 2012 nov 3]. Disponível em: <http://www.planalto.gov.br/ccivil_03/_ato 2007-2010/2009/lei/l11947.htm>.

4. Brasil. Resolução FNDE/CD n 26, de 17 de junho de 2013. Dispõe sobre o atendimento da alimentação escolar aos alunos da educação básica no Programa Nacional de Alimentação Escolar PNAE. Brasília: MEC; 2013 [acesso 2013 jun 17]. Disponível em: <http://www.fnde.gov.br/fnde/ legislacao/resolucoes/item/4620-resolu \% C3\%A7\%C3\%A3o-cd-fnde-n\%C2\%BA-26,-de17-de-junho-de-2013>.

5. Peres F, Moreira JC, Dubois GS. Agrotóxicos, saúde e ambiente: uma introdução ao tema. In: Peres, F. É veneno ou é remédio? Agrotóxicos, saúde e ambiente. Rio de Janeiro: Fiocruz; 2003. p.21-47.

6. Brasil. Ministério da Saúde. Manual de vigilância da saúde de populações expostas a agrotóxicos. Brasília: Organização Pan-Americana da Saúde; 1997.

7. Faria NMX, Fassa AG, Fachinni LA. Intoxicação por agrotóxicos no Brasil: os sistemas oficiais de informação e desafios para realização de estudos epidemiológicos. Ciênc Saúde Colet. 2007; 12(1):25-38. doi: 10.1590/\$1413-8123200700010 0008

8. Sarcinelli PN. Exposição de crianças e adolescentes a agrotóxicos. In: Peres F. É veneno ou é remédio? Agrotóxicos, saúde e ambiente. Rio de Janeiro: Fiocruz; 2003. p.43-58.

9. Silva APF, Sousa AA. Alimentos orgânicos da agricultura familiar no Programa Nacional de alimentação Escolar do Estado de Santa Catarina, Brasil. Rev Nutr. 2013; 26(6):701-14. doi: 10.1590/ S1415-52732013000600009

10. Conselho Federal de Nutricionista. Resolução CFN $n^{\circ} 465 / 2010$. Dispõe sobre as atribuições do nutricionista, estabelece parâmetros numéricos mínimos de referência no âmbito do Programa de Alimentação Escolar e dá outras providências. Diário Oficial da União. 2012 [acesso 2012 ago 23]. Disponível em: <http://www.cfn.org.br/novosite/arquivos/ Resol-CFN-465-atribuicao-nutricionista-PAE.pdf>.

11. Mello AL, Vidal Júnior PO, Sampaio LR, Santos LAS, Freitas MCS, Fontes GAV. Perfil do nutricionista do programa nacional de alimentação escolar na região Nordeste do Brasil. Rev Nutr. 2012; 25(1):119-32. doi: 10.1590/S1415-52732012000100011

12. Sidaner E, Balaban D, Burlandy L. The Brazilian school feeding programme: An example of an integrated programme in support of food and nutrition security. Public Health Nutr. 2012; 16(6):989-94. doi 10.1017/S1368980012005101

13. Brasil. Resolução FNDE/CD n 38, 16 de julho de 2009. Dispõe sobre o atendimento da alimentação escolar aos alunos da educação básica no Programa Nacional de Alimentação Escolar (PNAE). Brasília: Fundo Nacional de Desenvolvimento da Educação; 2009 [acesso 2014 abr 16]. Disponível em: <http:// www.fnde.gov.br/fnde/legislacao/resolucoes/item/ 3341-resolu \% C3\% A7\% C 3\% A3o-cd-fnde-n\% C2\%BA-38-de-16-de-julho-de-2009>.

14. Cunha E, Sousa AA, Machado NMV. A alimentação orgânica e as ações educativas na escola: diagnóstico para a educação em saúde e nutrição. Ciênc Saúde Colet. 15(1):39-49.

15. Chaves LG, Santana TCM, Gabriel CG, Vasconcelos FAG. Reflexões sobre a atuação do nutricionista no Programa Nacional de Alimentação Escolar no Brasil. Ciênc Saúde Colet. 2013; 18(4):917-26. doi: 10.15 90/S1413-81232013000400003

16. Fundo Nacional de Desenvolvimento da Educação. Projeto educando com a horta escolar. Brasília: FNDE; 2010 [acesso 2012 dez 18]. Disponível em: <www.educandocomahorta.org.br>.

17. Morgan PJ, Warren JM, Lubans DR, Saunders KL, Quick GI, Collins CE. The impact of nutrition education with and without a school garden on knowledge, vegetable intake and preferences and quality of school life among primary-school students. Public Health Nutr. 2010; 13(11):1931-40. doi: $10.1017 /$ S1368980010000959

18. Morgado FS. A horta escolar na educação ambiental e alimentar: experiência do projeto Horta Viva nas escolas municipais de Florianópolis. Extensio. 2008 [acesso 2013 maio 27]; 5(6):1-10. Disponível em: <http://www.periodicos.ufsc.br/index.php/ extensio/article/view/9531/8950>.

19. Santa Catarina. Conselho Regional de Nutricionistas. Manual de responsabilidade técnica. Florianopolis: CRN; 2011 [acesso 2013 maio 28]. Disponível em: <http://www.crn10.org.br/images/manual-deresponsabilidade-tecnica-crn10.pdf>.

20. Instituto Brasileiro de Geografia e Estatística. Pesquisa nacional por amostra de domicílios: segurança alimentar 2004-2009. Rio de Janeiro: IBGE; 2010 [acesso 2013 maio 27]. Disponível em: <http:// www.ibge.gov.br/home/estatistica/populacao/ seguranca_alimentar_2004_2009/pnadalimentar. pdf $>$.

21. Brasil. Ministério da Educação. Plataforma E-mec. Brasilia: MEC; 2013 [acesso 2013 maio 27]. Disponível em: <http://emec.mec.gov.br/>.

Received on: 1/11/2013

Final version on: 7/11/2014

Approved on: 8/5/2014 
